\title{
Experimental Studies on the Removal of Aluminium Ions from Synthetic Aqueous Solution by Hydroxyapatites
}

\author{
Doina Humelnicu, ${ }^{1, \star}$ Inga Zinicovscaia, ${ }^{2,3}$ Ionel Humelnicu ${ }^{1}$ \\ and Maria Ignat ${ }^{1}$ \\ ${ }^{1}$ Alexandru Ioan Cuza" University of Iasi, Faculty of Chemistry, Iasi, Romania \\ ${ }^{2}$ Department of Nuclear Physics, Joint Institute for Nuclear Research, Dubna, Russia \\ ${ }^{3}$ Department of Nuclear Physics, Horia Hulubei National Institute for RઐD in Physics and Nuclear Engineering, \\ Bucharest - Magurele, Romania \\ *Corresponding author: E-mail: doinah@uaic.ro
}

Received: 03-16-2021

\begin{abstract}
In this work we have presented the results obtained in the adsorption behavior of hydroxyapatite with different treatment towards aluminium ions from synthetic wastewaters. Experiments were performed in batch technique at different $\mathrm{pH}$ values, temperatures, sorbent dosage, contact time and initial aluminium concentration. The thermodynamic studies on the adsorption process of aluminium onto hydroxyapatite indicated that the process is spontaneous and endothermic. The Langmuir, Freundlich, Flory-Huggins, Dubinin-Radushkevich and Temkin equilibrium models were applied to the description of experimental data. The adsorption of aluminium follows the Langmuir adsorption isotherm. The kinetics of adsorption was evaluated using the pseudo-first order, pseudo-second order and intraparticle diffusion kinetic models. The rate of aluminium adsorption was successfully described by a pseudo-second-order kinetic model. The obtained results indicated that hydroxyapatite treated with Pluronic P123 surfactant has a higher sorption capacity toward aluminium ions $\left(117.65 \mathrm{mg} \mathrm{g}^{-1}\right)$ than hydroxyapatite treated with Pluronic F127 surfactant $\left(109.89 \mathrm{mg} \mathrm{g}^{-1}\right)$ while untreated hydroxyapatite exhibited the lowest one $\left(104.17 \mathrm{mg} \mathrm{g}^{-1}\right)$.
\end{abstract}

Keywords: Aluminium removal, adsorption, hydroxyapatite, wastewaters

\section{Introduction}

Wastewaters that contain metals are considered to be dangerous to both human and the environment due to their acute toxicity and non-biodegradability, even when the metals are present at very low concentrations. Metal ions are known as priority pollutants, due to their mobility and toxicity in natural water ecosystems.

Aluminium is usually present in alum treated water, effluents from aluminium based industries and also due to the salts of aluminum added to many processed foods and medicine. The main factors of the presence of aluminium in water are the industrial processes. Acid rains are the other important source for aluminium contamination of natural waters. ${ }^{1-3}$

The sources of aluminium contamination is attributed to the presence of 'residual aluminium' present in alum treated waters ${ }^{4,5}$ effluents from aluminium based industries and also due to the salts of aluminium being to human health. ${ }^{1-5}$ Aluminium is a neurotoxin when is added to many processed foods and medicine. ${ }^{6}$

Wastewaters that result from industrial activities regularly can pollute drinking water supplies as well as rivers, lakes, seawater and other aquatic ecosystems. In time, this can cause a contamination of water with aluminium and cause many medical disorders in living organisms. ${ }^{7,8}$

Harmfulness of aluminium can be attributed to its accumulation in bone and central nervous system, especially in people who have kidney failure. In high doses $\left(>110 \mu \mathrm{g} \mathrm{L}^{-1}\right),{ }^{9}$ aluminium can cause neurotoxicity being associated with Parkinson dementia, and Alzheimer's disease. ${ }^{10}$ Also, aluminium can reduce skeletal mineralization because it competes with calcium absorption in bones. 
For the removal of aluminium from wastewaters has been proposed several methods such as ion exchange, reverse osmosis, chemical precipitation, and solvent extraction. Such methods generate toxic sludge that constitutes serious environmental and economical problems. Consequently, the adsorption has been found to be a better method for removal of metals from wastewaters due to its simplicity, efficiency and low costs.

It has been reported different type of sorbents that have the capacity to adsorb and accumulate metals from wastewaters, mainly activated carbon, ${ }^{11,12}$ natural zeolites, ${ }^{13,14}$ different algae types, ${ }^{15,16}$ magnetic nanoparticles, ${ }^{17}$ rice hulk, polymers. ${ }^{18-21}$ Recently, among the widely available inorganic based adsorbents hydroxyapatite (HAP) was found to exhibit a good adsorption potential $^{22,23} \mathrm{HAP}$ is the most stable form of calcium phosphate with the chemical formula $\mathrm{Ca}_{10}\left(\mathrm{PO}_{4}\right)_{6}(\mathrm{OH})_{2}{ }^{24}$ being an efficient sorbent used in order to remove heavy metals from wastewaters due to its high sorption capacity ${ }^{25}$ and ion exchange properties. ${ }^{26}$ Different methods of synthesis influence the morphology of HAP, and, consequently cause some properties such as adsorption and mechanical strength. ${ }^{24,27,28}$ As a result of these properties HAP has been used as sensor, as adsorbent for dyes and heavy metals from residual waters. ${ }^{29-33}$

As nanostructured HAP provide large interfaces, giving great adsorption capability in the separation field ${ }^{30}$, the objective of this study was to evaluate the feasibility of using nanoporous hydroxyapatite with different available pore volumes and specific surface areas for the removal of aluminium from aqueous solution. Thus, we succeeded in synthesizing a mesoporous hydroxyapatite, using the surfactant micelle as template system in order to induce pores in HAP material. Further, the influence of experimental parameter such as contact time, sorbent dose, $\mathrm{pH}$, temperature, and initial $\mathrm{Al}(\mathrm{III})$ concentration were studied in the sorption process on prepared HAP powders. The adsorption process was studied from kinetic and isotherm standpoints.

\section{Material and Methods}

Calcium nitrate, aluminium nitrate and phosphoric acid were purchased from Sigma Aldrich. Ethylic alcohol and liquid ammonia were purchased from Chemical Company, and surfactants (Pluronic P123 and Pluronic F127) were purchased from Sigma Aldrich. All chemicals were reagent grade and were used without further purification.

\section{1. Sorbents Synthesis}

Hydroxyapatite (HAP) was prepared by coprecipitation of calcium nitrate and phosphoric acid according to the synthesis reported by Arsad and colab. ${ }^{30}$ with some modifications. Aqueous solution of $0.5 \mathrm{M}$ calcium nitrate was added to $50 \mathrm{~mL}$ ethanol and was vigorously stirred at room temperature. Afterward few drops of $25 \%(\mathrm{v} / \mathrm{v})$ ammonia solution were then added to the solution in order to adjust the $\mathrm{pH}$ to 10 , and then a solution of $0.3 \mathrm{M}$ phosphoric acid was added slowly in a dropwise manner to allow reacting with calcium nitrate. The used volumes of calcium and phosphate containing reagent solutions were calculated so as to respect the molar ratio of $\mathrm{Ca} / \mathrm{P}$ equal to 1.67 , as in the natural HAP. After $1 \mathrm{~h}$ reaction at $60^{\circ} \mathrm{C}$, the reaction mixture was allowed to age overnight at room temperature to complete the reaction. The suspension was centrifuged at 4,000 rpm for $15 \mathrm{~min}$., separated and dried at room temperature. The white powder of sample was calcined for 6 hours at $550{ }^{\circ} \mathrm{C}$ and labeled as HAP.

The HAP P123 and HAP F127 samples have been obtained following the same procedure with the mention that to the reaction mixture the corresponding surfactants were added. Thus, the Pluronic P123 has been used in the synthesis of HAP P123 sample, and Pluronic F127 in the synthesis of HAP F127 sample.

The $\mathrm{N}_{2}$ adsorption/desorption isotherms for BET specific surface area measurements were recorded on a NOVA 2200e (Quantachrome Instruments) automated gas adsorption analyzer. Before analysis the samples were outgassed at $120^{\circ} \mathrm{C}$ for at least $6 \mathrm{~h}$ under vacuum.

\section{2. Sorption Experiments}

Sorption of aluminium ions from synthetic wastewaters was carried out in batch mode to establish the sorption capacity of sorbents as function of contact time, $\mathrm{pH}$, initial concentration of aluminium ions, temperature, sorbent dose.

The aluminium ion concentration in the samples collected at different contact times and at equilibrium was measured at a wavelength of $309 \mathrm{~nm}$ by flame atomic absorption spectroscopy (FAAS) on the continuum source atomic absorption spectrometer-contrAA $A^{\oplus} 300$ - equipped with an optimized high-resolution Echelle double monochromator. Infrared spectra were performed with a BRUKER ALPHA FT-IR Spectrometer between $400-4000 \mathrm{~cm}^{-1}$.

Experiments were performed in triplicate and the average of measurements was used in calculation.

The amount of aluminium retained per unit mass of sorbent was calculated with Eq. (1).

$$
q=\frac{\left(C_{0}-C_{e}\right) \cdot V}{m},(\mathrm{mg} \mathrm{Al} / \mathrm{g} \text { sorbent })
$$

where $\mathrm{C}_{0}$ is initial concentration of aluminium, $\left(\mathrm{mg} \mathrm{L}^{-1}\right)$, $\mathrm{C}_{e}$ is aluminium concentration in aqueous solution at equilibrium, $\left(\mathrm{mg} \mathrm{L}^{-1}\right), \mathrm{V}$ is the volume of aqueous solution $(\mathrm{L})$, and $\mathrm{m}$ is sorbent mass $(\mathrm{g})$.

\section{Results and Discussion}

Infrared spectra of the sorbent point out that the use of surfactants did not influence their surface chemistry, 
but only changed their textural properties, meaning that the specific surface area and pores volume increased/decreased according to the used structure directing agent. The infrared spectra show broad bands characteristic to hydroxyapatite nanomaterial. The characteristic peaks attributed to $\mathrm{PO}_{4}{ }^{3-}$ appear at 475, 570, 600, 962, 1039, and $1091 \mathrm{~cm}^{-1}$, showing a distinguishable P-O stretching vibration and a triple degenerate bending vibrations of phosphate groups in hydroxyapatite. ${ }^{34}$ The FTIR spectra after adsorption experiments highlight the increase in the intensity of some absorption bands.

Nitrogen adsorption-desorption analysis has been employed to characterize the porous structure of the synthesized samples. ${ }^{35}$ Figure 1 shows typical isotherms char-
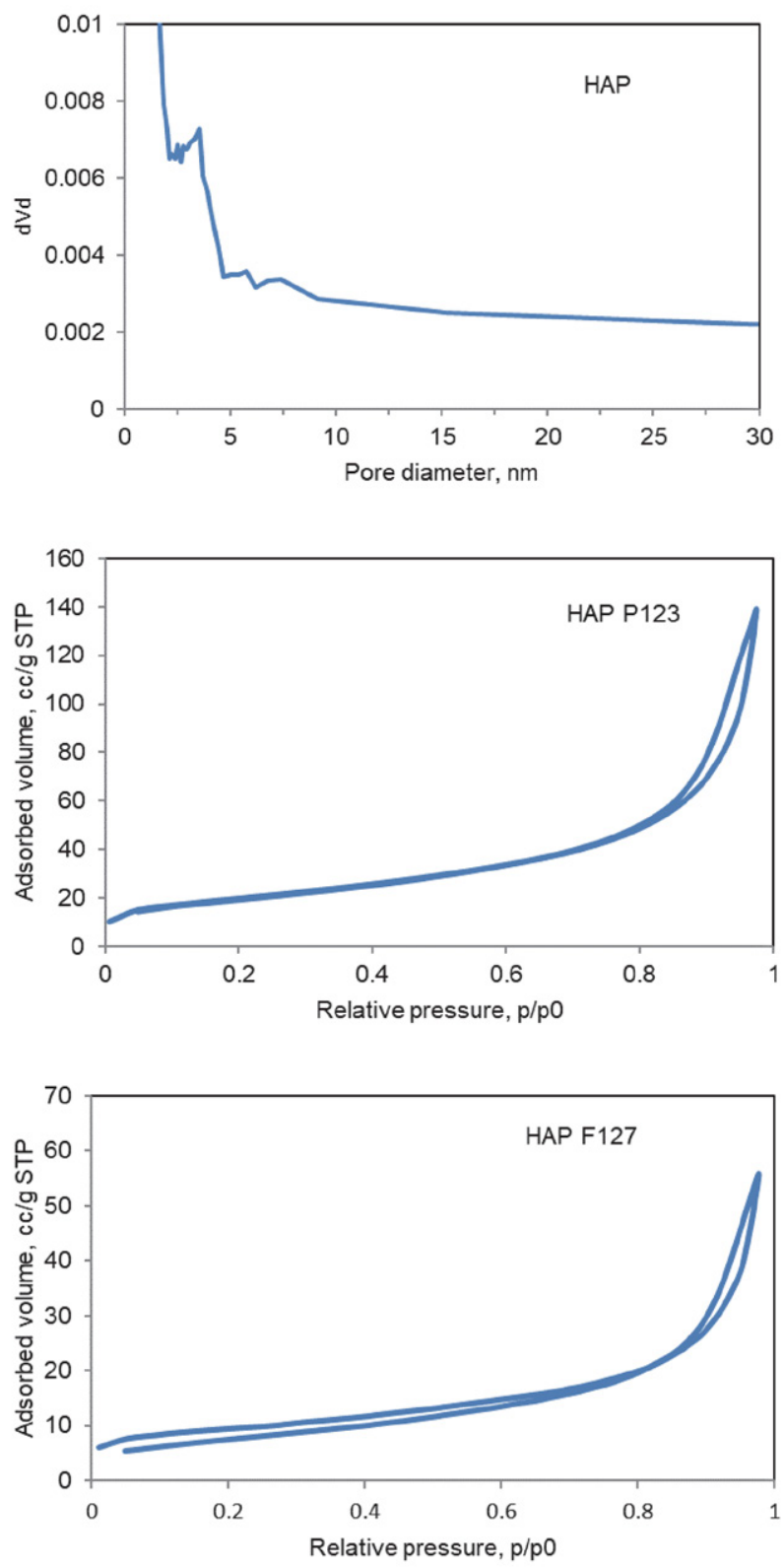

Figure 1. Nitrogen sorption isotherm and corresponding pore size distributions for the synthesized HAP samples. acteristic to hydroxyapatite materials. All isotherms are of type IV, characterizing mesoporous materials, accompanied by a $\mathrm{H} 3$ type hysteresis loop, which according to IUPAC classification ${ }^{36}$ is attributed to the formation of aggregated plate-lite particles giving rise to pores of slit shapes.

The textural characteristics of the investigated sorbents are presented in Table 1. It can be observed that the surfactant addition during the HAP synthesis lead to the hypothesis that the abundant pore bodies of a certain size can be correlated with the abundance of pore necks that are smaller by a systematic amount. ${ }^{37}$ Even more, the surfactant P123 increased considerably specific surface area and total pore volume of the hydroxyapatite material, as can be observed from the Table 1 .

Table 1. Textural properties of the synthesized sorbents.

\begin{tabular}{lccc} 
Sorbent & $\begin{array}{c}\text { Specific surface, } \\
\mathbf{m}^{\mathbf{2}} \mathbf{g}\end{array}$ & $\begin{array}{c}\text { Pore Volume, } \\
\mathbf{c m}^{\mathbf{3}} / \mathbf{g}\end{array}$ & $\begin{array}{c}\text { Pore diameter, } \\
\mathbf{n m}\end{array}$ \\
\hline HAP & 47.251 & $6.48 \times 10^{-2}$ & 3.12 \\
HAP P123 & 69.153 & $1.59 \times 10^{-1}$ & 3.50 \\
HAP F127 & 31.719 & $6.18 \times 10^{-2}$ & 4.13 \\
\hline
\end{tabular}

Relatively large specific surface and pore volume of the synthesized HAP systems highlighted their potential application as adsorbent materials.

\section{1. Influence of Sorbent Mass on the Adsorption Process}

An important factor influencing the efficiency of the adsorption process from economically point of view is the sorbent mass used to remove the pollutant. The adsorption process is not effective if it requires a large amount of sorbent.

The effect of sorbent mass variation on the adsorption process was investigated at an established metal ion

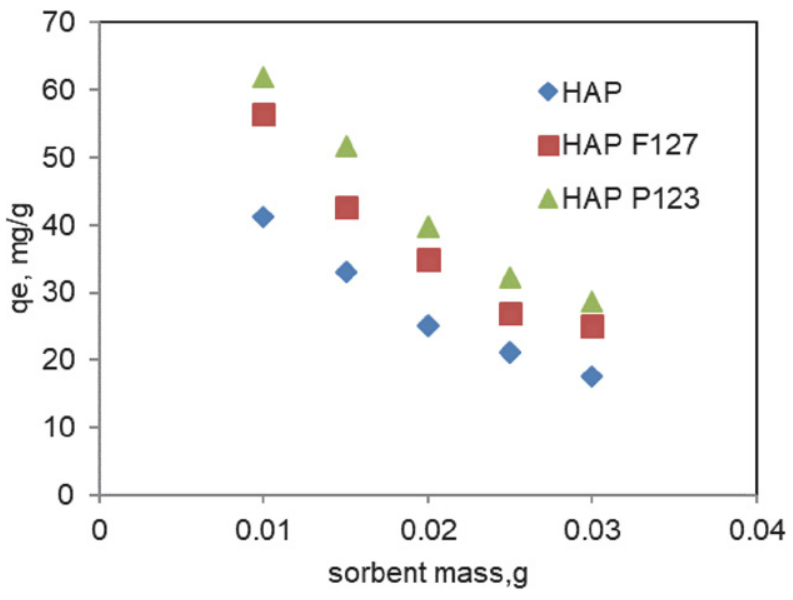

Figure 2. Dependence of adsorption process on the sorbent mass. 
concentration of $50 \mathrm{mg} \mathrm{L}^{-1}$ at a temperature of $25^{\circ} \mathrm{C}$. Figure 2 shows that with the increase of the sorbent mass from $0.01 \mathrm{~g}$ to $0.03 \mathrm{~g}$ the sorption capacity of the sorbents decreases because by increasing of the sorbent dose the number of accessible active sites increased consequently, the same amount of aluminium ions being distributed on an increasing number of binding sites. From this figure we can conclude that HAP P123 had a better sorption capacity by comparing with HAP and HAP F127, exhibiting almost similar textural properties.

\section{2. Effect of Contact Time on the Sorption Process}

The influence of contact time on the adsorption of aluminium ions on the three type of hydroxyapatite was studied in a range of $0-180$ minutes.

These experiments were performed at a temperature of $25^{\circ} \mathrm{C}$ and a metal ion concentration of $50 \mathrm{mg} \mathrm{L}^{-1}$, the sorbent mass used was $15 \mathrm{mg}$ and the working volume of the solution was $20 \mathrm{~mL}$. The results that were obtained are plotted in Figure 3.

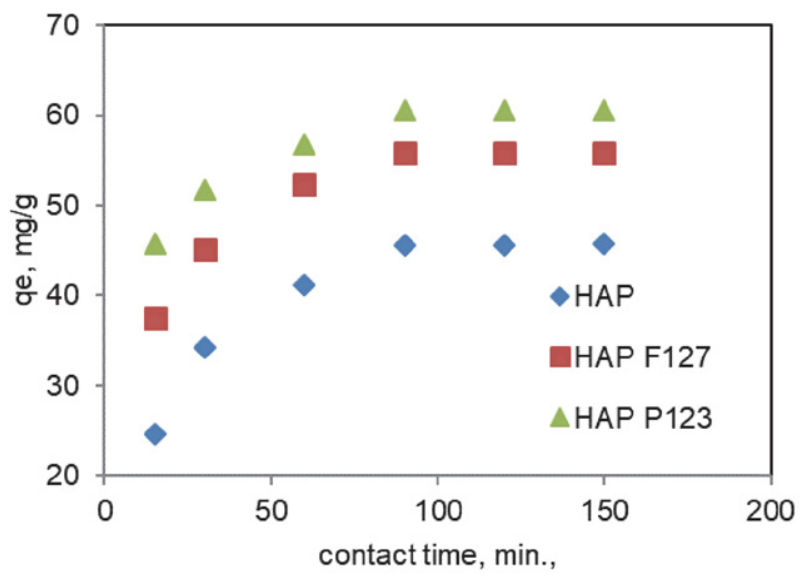

Figure 3. Dependence of adsorption process on the contact time.

It can be seen from Figure 3 that the amount of aluminium ions retained by sorbents increases with the increasing of the contact time, and equilibrium is reached after a period of 90 minutes after which the sorption remains constant. It is noted that in the case of the hydroxyapatite treated with surfactant Pluronic P123, the sorption of the aluminium ions was more efficient.

\section{3. pH Dependence of Sorption Process}

$\mathrm{pH}$ is an important parameter that determines the ionic species in aqueous solution. The $\mathrm{pH}$ effect on the sorption of aluminium ions was studied by varying the solution $\mathrm{pH}$ in the range 2-8 with $\mathrm{HCl}$ and $\mathrm{NaOH}$, the sorption capacity of HAPs sorbents being plotted as a function of $\mathrm{pH}$ in Figure 4. It is obvious that the sorption capacity is influenced by the solution $\mathrm{pH}$, the higher sorption occurring at $\mathrm{pH} 4$. The value of sorption capacity of HAP was $43.21 \mathrm{mg} \mathrm{g}^{-1}$, for HAP F127 was $52.64 \mathrm{mg} \mathrm{g}^{-1}$ and for HAP P123 was $59.85 \mathrm{mg} \mathrm{g}^{-1}$, respectively. In aqueous solutions the solubility of aluminum increases at low $\mathrm{pH}$ due to the formation of ionic species: $[\mathrm{Al}(\mathrm{OH})]^{2+}$, $\left[\mathrm{Al}(\mathrm{OH})_{2}\right]^{+}$and $\left[\mathrm{Al}\left(\mathrm{H}_{2} \mathrm{O}\right)_{6}\right]^{3+} .{ }^{18}$ At $\mathrm{pH}$ values $\sim 4$, most $\mathrm{Al}$ exists as $\mathrm{Al}^{3+} .{ }^{38} \mathrm{In} \mathrm{pH}$ range between 5.2 and 8.8 the predominant specie is solid $\mathrm{Al}(\mathrm{OH})_{3}$ while over $\mathrm{pH} 9$ the soluble $\left[\mathrm{Al}(\mathrm{OH})_{4}\right]^{-}$is dominant species.

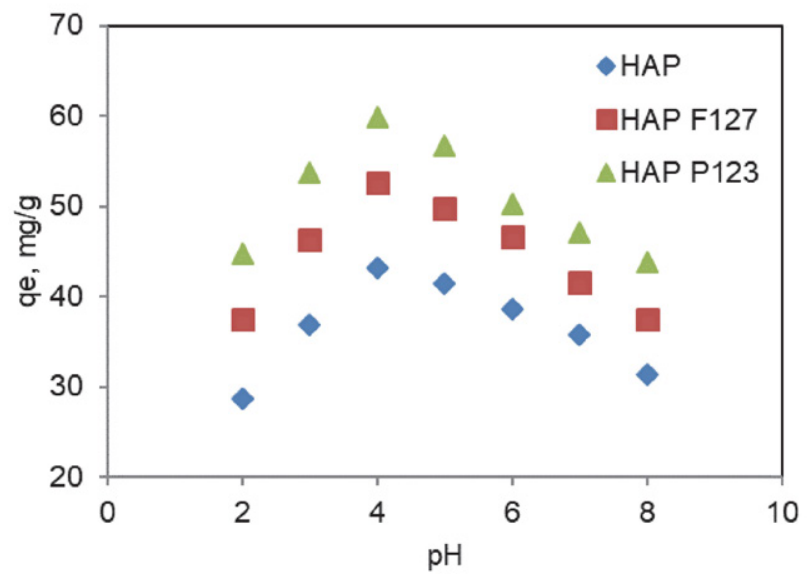

Figure 4. Influence of $\mathrm{pH}$ values on the adsorption process of $\mathrm{Al}(\mathrm{I}-$ III) ions.

The increase in $\mathrm{pH}$ values leads to the increase of the $\mathrm{Al}(\mathrm{III})$ ions removal (Fig. 4), it reaches a maximum at $\mathrm{pH} 4$ and thereafter, it decreases, probably due to the formation of the aluminum hydroxide which block the pores of the sorbent. ${ }^{39,40}$ It is well known that hydroxyapatite contains two different ionic $\mathrm{Ca}$ and $\mathrm{P}$ binding sites on their surface, depending on the $\mathrm{pH}$ values of the solution, that are able to absorb or release protons as follow: ${ }^{41}$

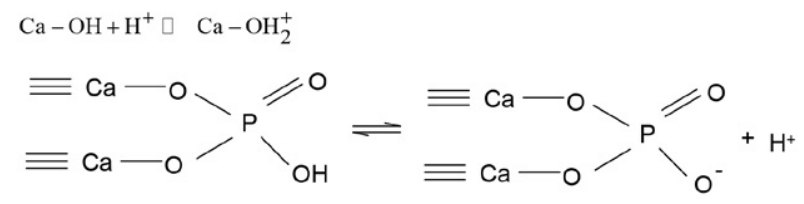

At low $\mathrm{pH}$ values the metal ions removal is weak due to the competition between the hydronium ions present in solution and the metal ions to occupy the surface-active sites. As the solution $\mathrm{pH}$ increases, this competition decreases and the sites from the hydroxyapatite surface become negatively charged and favors the adsorption of $\mathrm{Al}$ (III) ions by electrostatic interactions. Furthermore, some researchers have investigated the effect of $\mathrm{pH}$ on sorption of $\mathrm{Al}(\mathrm{III})$ using different kinds of sorbents and reported almost same $\mathrm{pH}$ dependent and maximum sorption was obtained at near $\mathrm{pH}$ values. 9,10 


\section{4. Effect of Initial Concentration of Aluminium Ions on the Sorption Process}

The effect of initial concentration on the adsorption of aluminium ions has also been investigated. Studies were performed at $25^{\circ} \mathrm{C}$, the initial concentration of aluminium ions was varied from 25 to $250 \mathrm{mg} \mathrm{L}^{-1}$ all other parameters have been maintained at constant values $(\mathrm{pH} \mathrm{4}$, contact time being 90 minutes and sorbent mass $-0.015 \mathrm{~g}$ ).

From Figure 5 it can be seen that the sorption process increases with increasing the concentration of aluminum ions up to a value of $100 \mathrm{mg} \mathrm{L}^{-1}$ after which a decrease of the adsorption process is observed. This variation can be explained by the fact that at high concentration the sorbent binding sites are saturated and other metal ions cannot be retained. Moreover, in dilute solutions the mobility of the metal ions is high and, consequently, their interaction with the sorbent is high. For an efficient removal of metal ions from wastewater, it is suggested to dilute the water containing metal ions prior to the adsorption operation.

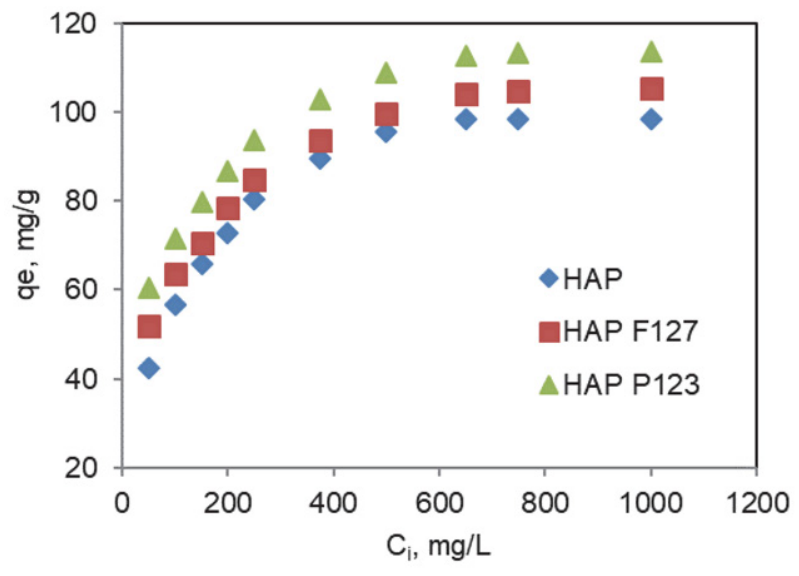

Figure 5. Influence of initial aluminium concentration on the adsorption process.

\section{5. Influence of Temperature on the Adsorption Process}

The effect of the temperature on the adsorption processes of aluminium ions on the three sorbents was investigated in a temperature range of $20-40{ }^{\circ} \mathrm{C}$ while the other parameters were kept constant and the results obtained are shown in Figure 6.

Increasing the amount of adsorbed metal with increasing temperature indicates the endothermic nature of this process. This variation can be attributed either to the increase in the number of active sites on the sorbent surface available for sorption, or to the decrease in the thickness of the boundary layer surrounding the adsorbent so that the resistance of the adsorbent layer to the mass transfer decreases. Another explanation may be that with the

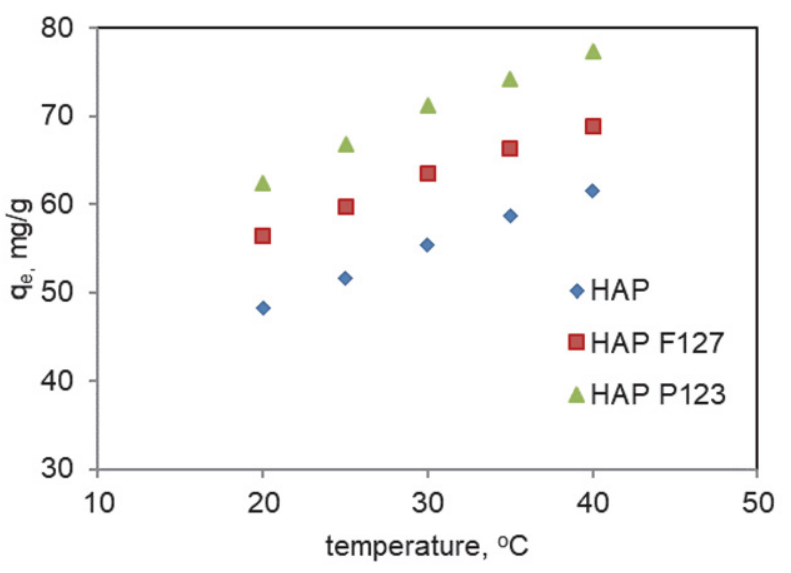

Figure 6. Dependence of adsorption process of $\mathrm{Al}$ (IIII) ions on the temperature.

increase in temperature the diffusion rate of the sorbate molecules increases along the outer layer, as well as in the internal pores of the sorbent particles.

\section{6. Thermodynamic study}

The distribution coefficient, $\mathrm{K}_{\mathrm{d}}$, is the ratio between the concentration of the aluminium ions in the sorbent and in aqueous solution at equilibrium, and it is calculated with the Equation (3).

$$
\mathrm{K}_{\mathrm{d}}=\frac{\left(\mathrm{C}_{0}-\mathrm{C}_{\mathrm{e}}\right)}{\mathrm{C}_{\mathrm{e}}} \cdot \frac{\mathrm{V}}{\mathrm{m}}\left(\mathrm{mL} \cdot \mathrm{g}^{-1}\right)
$$

where $C_{0}$ is initial concentration of aluminium, $\left(\mathrm{mg} \mathrm{L}^{-1}\right)$, $\mathrm{C}_{\mathrm{e}}$ is aluminium concentration in aqueous solution at equilibrium, $\left(\mathrm{mg} \mathrm{L}^{-1}\right), \mathrm{V}$ is the volume of aqueous solution $(\mathrm{L})$, and $\mathrm{m}$ is sorbent mass $(\mathrm{g})$.

The thermodynamic parameters, such as: the standard free energy $\left(\Delta \mathrm{G}^{\circ}\right)$, enthalpy $\left(\Delta \mathrm{H}^{\circ}\right)$, and entropy of the system $\left(\Delta S^{\circ}\right)$ were estimated using Eqs. (4) and (5).

$$
\begin{aligned}
& \ln K_{d}=\frac{\Delta S^{0}}{R}-\frac{\Delta H^{0}}{R T} \\
& \Delta G^{0}=\Delta H^{0}-T \Delta S^{0}
\end{aligned}
$$

For the calculation of the thermodynamic parameters were used the results obtained from the study of temperature influence on the adsorption process. The values of $\Delta \mathrm{H}^{\circ}$ and $\Delta S^{\circ}$ were calculated from the slope and the ordered intercept of the $1 / \mathrm{T}$ function representation of $\ln \mathrm{K}_{\mathrm{d}}$ (Figure 7). The results obtained are presented in Table 2.

\section{7. Adsorption Isotherms Models}

Adsorption isotherms are an important aspect in describing the adsorption phenomenon that occurs at different types of interfaces. Among the various isotherm models, the most common were used in this study. 
Table 2. Thermodynamic parameters of the adsorption process of $\mathrm{Al}(\mathrm{III})$ ions.

\begin{tabular}{lccccccc}
\hline Sorbent & \multicolumn{7}{c}{$\Delta \mathbf{G}^{\mathbf{0}}, \mathbf{k J} / \mathbf{m o l}$} \\
\hline & $\begin{array}{c}\boldsymbol{\Delta} \mathbf{H}^{\circ} \\
\mathbf{k J} / \mathbf{m o l ~ K}\end{array}$ & $\begin{array}{c}\boldsymbol{\Delta} \mathbf{S}^{\circ} \\
\mathbf{k J} / \mathbf{m o l ~ K}\end{array}$ & 293 & 298 & 303 & 308 & 313 \\
\hline HAP & 21.01 & 0.128 & -16.49 & -17.13 & -17.77 & -18.41 & -19.05 \\
HAP 127 & 20.54 & 0.130 & -17.55 & -18.2 & -18.85 & -19.5 & -20.15 \\
HAP 123 & 27.87 & 0.156 & -17.84 & -18.62 & -19.40 & -20.18 & -20.96 \\
\hline
\end{tabular}

The positive values obtained for $\Delta \mathrm{H}^{\circ}$ and $\Delta \mathrm{S}^{\circ}$ indicate that the adsorption process is endothermic, and the affinity of the three sorbents for the aluminium ions is high. Negative Gibbs energy values show that the adsorption process is spontaneous.

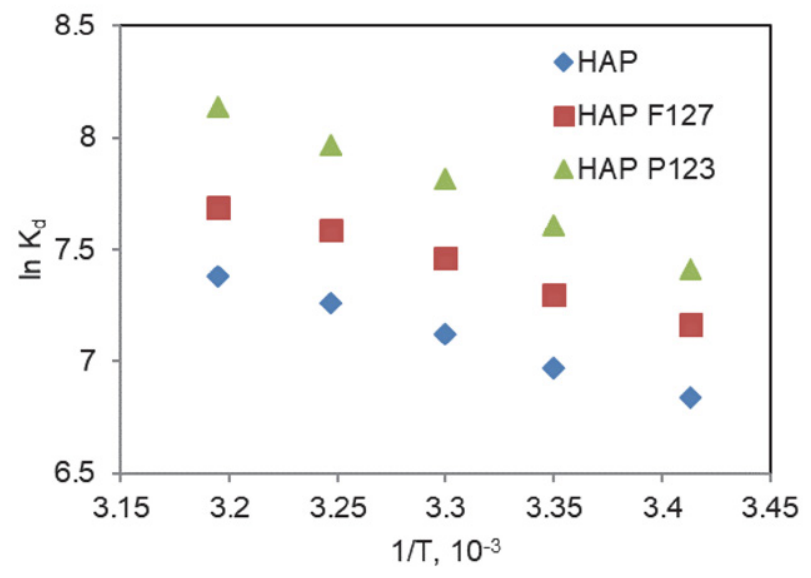

Figure 7. Dependence of distribution coefficient on the temperature.

\section{Langmuir isotherm model}

The Langmuir model is widely applied to the metal ion sorption processes. This model describes the quantitative adsorption of a monolayer on the external surface of the sorbent, after which no further adsorption occurs. ${ }^{42}$ Thus, the Langmuir isotherm is the balanced distribution of metal ions between the solid and liquid phases. The model implies uniform adsorption energy on the surface of the sorbent and no transmigration of the adsorbate in the surface plane. The Langmuir isotherm involves a surface with homogeneous binding points, equivalent sorption energies and excludes any type of interaction between the adsorbed species. The linearized mathematical expression of this isotherm is: ${ }^{42}$

$$
\frac{\mathrm{C}_{\mathrm{e}}}{\mathrm{q}_{\mathrm{e}}}=\frac{1}{\mathrm{~K}_{\mathrm{L}} \cdot \mathrm{q}_{\mathrm{m}}}+\frac{\mathrm{C}_{\mathrm{e}}}{\mathrm{q}_{\mathrm{m}}}
$$

where $\mathrm{C}_{\mathrm{e}}$ is aluminium ions concentration at equilibrium $\left(\mathrm{mg} \mathrm{L}^{-1}\right), \mathrm{q}_{\mathrm{e}}$ is amount of $\mathrm{Al}$ (III) adsorbed at equilibrium $(\mathrm{mg} / \mathrm{g}), \mathrm{q}_{\max }$ is maximum adsorption capacity of the sorbent $(\mathrm{mg} / \mathrm{g})$ and $\mathrm{K}_{\mathrm{L}}$ is Langmuir adsorption constant ( $\mathrm{L} /$ $\mathrm{mg}$ ). The plot of $\mathrm{C}_{\mathrm{e}} / \mathrm{q}_{\mathrm{e}}$ in function of $\mathrm{C}_{\mathrm{e}}$ (Figure 8a) gives a straight line with slope $1 / \mathrm{q}_{\max }$ and intercept $1 / \mathrm{q}_{\max } \mathrm{K}_{\mathrm{L}}$. $\mathrm{K}_{\mathrm{L}}$ is a constant that is important in calculating the dimensional parameter $\left(\mathrm{R}_{\mathrm{L}}\right)$ that explains the favorability of the adsorption process; $\mathrm{R}_{\mathrm{L}}$ is calculated using Eq. (7)

$$
\mathrm{R}_{\mathrm{L}}=\frac{1}{1+\mathrm{K}_{\mathrm{L}} \mathrm{C}_{0}}
$$

Thus, 4 situations are distinguished, namely: 1) the adsorption process is unfavorable if $\mathrm{R}_{\mathrm{L}}>1 ; 2$ ) adsorption is linear when $R_{L}=1 ; 3$ ) the adsorption process is favorable when $0<\mathrm{R}_{\mathrm{L}}<1$ and 4) the adsorption is irreversible if $\mathrm{R}_{\mathrm{L}}=$ 0 . In the studies that were performed we obtained for $\mathrm{R}_{\mathrm{L}}$ subunit values (Table 3 ) which proves that the adsorption process of the aluminum ions on the three sorbents was favorable. ${ }^{39}$

\section{Freundlich isotherm model}

The Freundlich isotherm is an empirical model that is not limited to monolayer adsorption, but also to the description of multilayer adsorption. The mathematical expression of the linearized form is: ${ }^{43}$

$$
\log \mathrm{q}_{\mathrm{e}}=\log \mathrm{K}_{\mathrm{F}}+\frac{1}{\mathrm{n}} \log \mathrm{C}_{\mathrm{e}}
$$

where $\mathrm{q}_{\mathrm{e}}$ is amount of $\mathrm{Al}$ (III) adsorbed at equilibrium $(\mathrm{mg} / \mathrm{g}), \mathrm{C}_{\mathrm{e}}$ is concentration of $\mathrm{Al}(\mathrm{III})$ in aqueous solution at equilibrium $(\mathrm{mg} / \mathrm{L}) ; \mathrm{K}_{\mathrm{F}}$ and $\mathrm{n}$ are Freundlich constants that include factors that affect adsorption capacity and adsorption intensity, respectively. Graphical representation of $\log \mathrm{q}_{\mathrm{e}}$ as function of $\log \mathrm{C}_{\mathrm{e}}$ (Figure $8 \mathrm{~b}$ ) gives a linear graph with slope $1 / \mathrm{n}$ and intercept $\log \mathrm{K}_{\mathrm{F}}$ from which Freundlich constants were estimated (Table 3 ).

\section{Flory-Huggins isotherm model}

For a complete characterization of the adsorption process the Flory-Huggins model was used to determine the degree of sorbent surface coverage of the sorbate. ${ }^{44}$ The linearized mathematical expression of this isotherm is:

$$
\log \frac{\theta}{\mathrm{C}_{0}}=\log \mathrm{K}_{\mathrm{FH}}+\mathrm{n} \log (1-\theta)
$$

where ${ }^{\theta=}\left(1-\frac{C_{e}}{C_{0}}\right)$ is the degree of coverage of the surface, and $\mathrm{KFH}$ is the equilibrium constant of the adsorption. The parameters of Eq. (9) are calculated from the slope and 

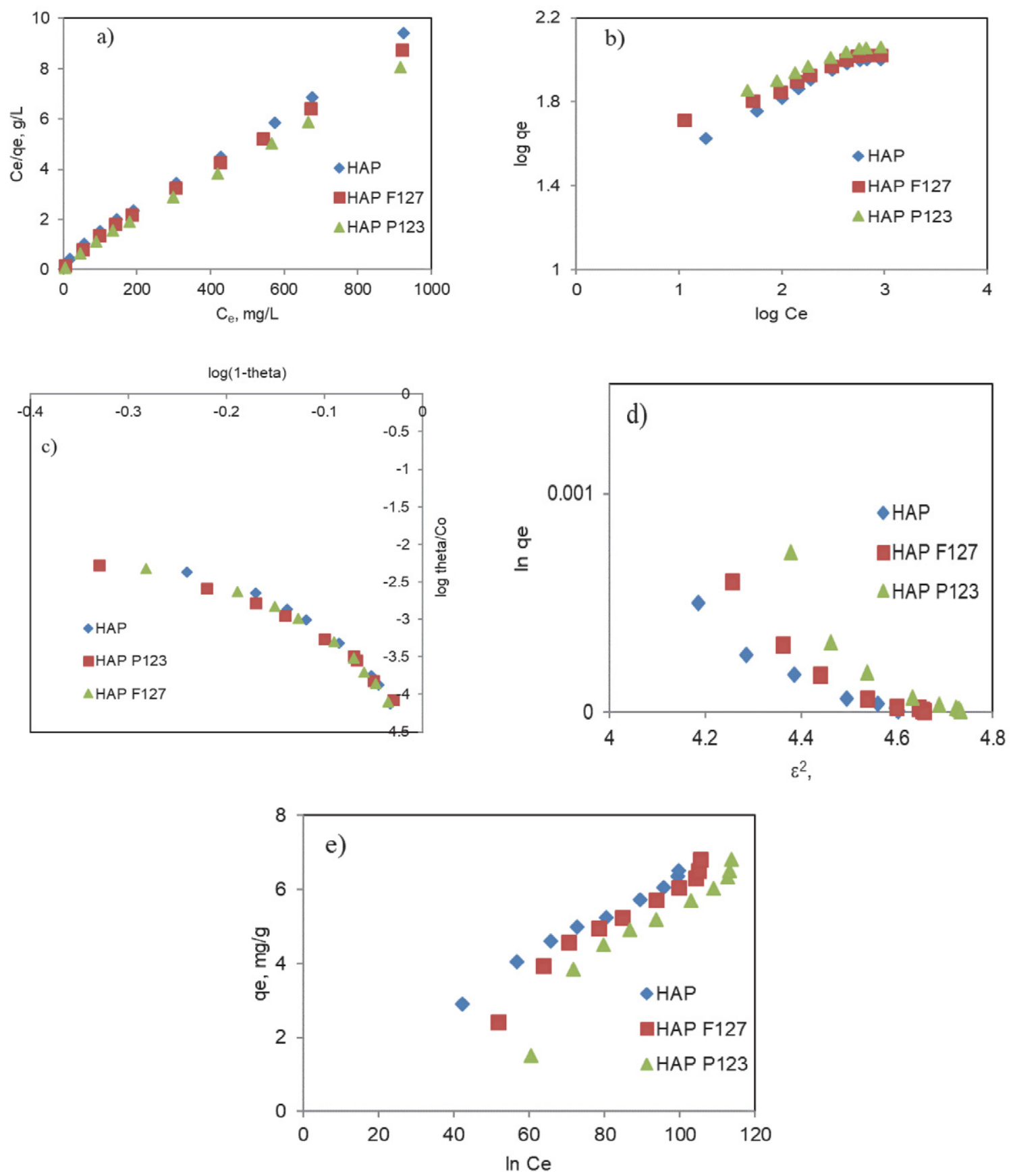

Figure 8. Langmuir (a), Freundlich (b), Flory-Huggins (c), Dubinin-Radushkevich (d) and Temkin (e) isotherms.

intercept of the graphical representation of $\log \theta / \mathrm{C}_{0} v s \log$ $(1-\theta)$, (Figure 8c) and their values are given in Table 3.

\section{Dubinin-Radushkevich isotherm model}

Dubinin and Radushkevich proposed another isotherm that is applied to estimate the average free energy of adsorption. The average free adsorption energy per mole of sorbent is the energy required to transfer one mole of adsorbate from solution from infinity to the surface, and is useful in evaluating the nature of the interaction between metal ions and binding sites. ${ }^{45}$ If the value of $\mathrm{E}$ is between 8 and $16 \mathrm{~kJ} /$ mol, it can be assumed that the adsorption process involves chemical sorption. In contrast, values of less than $8 \mathrm{~kJ} / \mathrm{mol}$ indicate that the adsorption process is physical in nature.

$$
\ln \mathrm{q}_{\mathrm{e}}=\ln \mathrm{X}_{\mathrm{m}}-\mathrm{K}_{\mathrm{DR}} \varepsilon^{2}
$$

where $K_{D R}$ is a constant related to adsorption energy $\left(\mathrm{mol}^{2} / \mathrm{kJ}^{2}\right), \mathrm{X}_{\mathrm{m}}$ is a constant that indicates the sorption capacity of sorbent $(\mathrm{mg} / \mathrm{g})$. 
Polanyi potential, $\varepsilon$, was calculated with the Eq. (11):

$$
\varepsilon=\mathrm{RT} \ln \left(1+\frac{1}{\mathrm{C}_{\mathrm{e}}}\right)
$$

The free adsorption energy (E) was calculated using the following expression:

$$
\mathrm{E}_{\mathrm{s}}=\left(-2 \mathrm{~K}_{\mathrm{DR}}\right)^{-1 / 2}
$$

The positive values obtained (see Table 3 ) indicate that the adsorption process is endothermic, being favored by high temperatures. Also, the values obtained are greater than $8 \mathrm{~kJ} / \mathrm{mol}$, indicating a chemisorption process.

\section{Temkin isotherm model}

This isotherm model considers the interactions between sorbent and adsorbate. This model assumes that the heat of adsorption process decreases linearly with the increase in coverage of sorbent, and the process is characterized by uniform distribution of the binding energies up to a maximum binding energy. ${ }^{46}$ The linearized form of this isotherm is given by the equation (13):

$$
q_{e}=\frac{R T}{b_{T}} \cdot \ln K_{T}+\frac{R T}{b_{T}} \ln C_{e}
$$

$1 / b_{T}$ indicates the sorption potential of the sorbent, and $\mathrm{K}_{\mathrm{T}}$ is Temkin constant being calculated for each material and are given in Table 3.

Table 3. Adsorption isotherm parameters.

\begin{tabular}{llll}
\hline Model & HAP & HAP F127 & HAP P123 \\
\hline Langmuir & & & \\
$\mathrm{q}_{\mathrm{m}},\left(\mathrm{mg} \mathrm{g}^{-1}\right)$ & 104.17 & 109.89 & 117.65 \\
$\mathrm{~K}_{\mathrm{L}}\left(\mathrm{L} \mathrm{g}^{-1}\right)$ & 0.021 & 0.023 & 0.03 \\
$\mathrm{R}_{\mathrm{L}}$ & 0.49 & 0.47 & 0.4 \\
$\mathrm{R}^{2}$ & 0.998 & 0.997 & 0.998 \\
\hline Freundlich & & & \\
$\mathrm{K}_{\mathrm{F}}$ & 37.54 & 32.59 & 22.58 \\
$\mathrm{n}$ & 5.82 & 5.58 & 4.32 \\
$\mathrm{R}^{2}$ & 0.974 & 0.98 & 0.978 \\
\hline Flory-Huggins & & & \\
$\mathrm{K}_{\mathrm{FH}}$ & $15.28 \times 10^{3}$ & $12.07 \times 10^{3}$ & $9.18 \times 10^{3}$ \\
$\mathrm{n}$ & 8.505 & 7.124 & 5.87 \\
$\mathrm{R}^{2}$ & 0.934 & 0.913 & 0.908 \\
\hline $\mathrm{Dubinin}^{2}$ Radushkevich & & \\
$\mathrm{K}_{\mathrm{DR}}$ & 0.001 & 0.0013 & 0.0017 \\
$\mathrm{X}_{\mathrm{m}}\left(\right.$ mol g$\left.^{-1}\right)$ & 102.48 & 105.61 & 109.48 \\
$\mathrm{E}\left(\mathrm{kJ} \mathrm{mol}{ }^{-1}\right)$ & 22.36 & 19.61 & 17.14 \\
$\mathrm{R}^{2}$ & 0.931 & 0.906 & 0.863 \\
\hline Temkin & & & \\
$\mathrm{b}_{\mathrm{T}}$ & 4.35 & 5.79 & 44.26 \\
$\mathrm{~K}_{\mathrm{T}}\left(\mathrm{L} \mathrm{g}^{-1}\right)$ & 3.44 & 6.33 & 9.38 \\
$\mathrm{R}^{2}$ & 0.983 & 0.944 & 0.989 \\
\hline
\end{tabular}

The results show that the Langmuir isotherm is the one that best describes the adsorption process of aluminium ions on the three sorbents, with a maximum adsorption capacity of $104.17 \mathrm{mg} \mathrm{g}^{-1}$ for simple hydroxyapatite, $109.89 \mathrm{mg} \mathrm{g}^{-1}$ for hydroxyapatite synthesized in the presence of Pluronic F127 and $117.65 \mathrm{mg} \mathrm{g}^{-1}$ for hydroxyapatite synthesized in the presence of Pluronic P123. In all three cases, a correlation coefficient of 0.99 was obtained. The high energy adsorption value indicates a chemisorption process for the absorption of aluminium ions.

\section{8. Kinetic Studies}

Kinetic studies are very important for adsorption processes because they can predict the rate at the pollutants are removed from aqueous solutions and offer some data to understand the mechanism of adsorption. In present study, three known kinetic models were used to investigate the adsorption mechanism.

\section{Pseudo first order kinetic model}

Lagergren showed that the rate of adsorption of ions on the sorbent is based on the adsorption capacity. ${ }^{47}$ Thus, we use a pseudo-order equation for estimating the constant rate, $k_{1}$. The nonlinear form of this equation is:

$$
\frac{d q_{t}}{d t}=k_{1}\left(q_{e}-q_{t}\right)
$$

Linearized form of this equation is:

$$
\log \left(\mathrm{q}_{\mathrm{e}}-\mathrm{q}_{\mathrm{t}}\right)=\log \mathrm{q}_{\mathrm{e}}-\frac{\mathrm{k}_{1}}{2.303} \mathrm{t}
$$

where $\mathrm{q}_{\mathrm{e}}$ and $\mathrm{q}_{\mathrm{t}}$ are the amounts of $\mathrm{Al}(\mathrm{III})(\mathrm{mg} / \mathrm{g})$ adsorbed at equilibrium and at $t(\mathrm{~min})$ time, respectively, and $\mathrm{k}_{1}(1 /$ $\mathrm{min}$ ) is the rate constant of pseudo-first order. The values of $\mathrm{k}_{1}$ are calculated from the graphical representation of $\log (\mathrm{qe}-\mathrm{qt}) v s . \mathrm{t}$ (Figure 9a).

\section{Pseudo-second order kinetic model}

This model is widely used for metal ion/sorbent adsorption systems. Adsorption of $\mathrm{Al}$ (III) ions may involve a chemical adsorption assuming a strong electrostatic interaction between the negatively charged surface of the sorbent and the metal ions. ${ }^{48}$ The pseudo-second order kinetic equation is described in the following form:

$$
\frac{\mathrm{dq}_{\mathrm{t}}}{\mathrm{dt}}=\mathrm{k}_{2}\left(\mathrm{q}_{\mathrm{e}}-\mathrm{q}_{\mathrm{t}}\right)^{2}
$$

Linearized form of this equation is:

$$
\frac{1}{\mathrm{q}_{\mathrm{t}}}=\frac{\mathrm{l}}{\mathrm{k}_{2} \mathrm{q}_{\mathrm{e}}^{2}}+\frac{1}{\mathrm{q}_{\mathrm{e}}} \mathrm{t}
$$

where $\mathrm{k}_{2}(\mathrm{~g} / \mathrm{mg} \mathrm{min})$ is the rate constant of second order. Linear form of $t / q_{t}$ as function of $t$ is shown in Figure $9 b$. 


\section{Intraparticle diffusion kinetic model}

The kinetic model of intra-particle diffusion is based on the theory or equation proposed by Weber and Morris. It is a functional empirical relationship, common with most adsorption processes. ${ }^{49}$ Metal ions adsorption varies almost proportionally with $t^{1 / 2}$ rather than with contact time, $t$. Weber-Morris equation is:

$$
\mathrm{q}_{\mathrm{t}}=\mathrm{k}_{\mathrm{id}} \mathrm{t}^{1 / 2}+\mathrm{C}_{\mathrm{i}}
$$

where $\mathrm{k}_{\mathrm{id}}$ is rate parameter of the $i$ step $\left(\mathrm{mg} / \mathrm{g} \mathrm{min}{ }^{1 / 2}\right)$, estimated from the slope of linear plot qt as function of $t^{1 / 2} \cdot C_{i}$ is intercept of $i$ step, giving an idea about the thickness of the boundary layer, that since the intercept is greater, the boundary layer effect is greater. For intra-particle diffusion, the plot of $\mathrm{q}_{\mathrm{t}} v s . \mathrm{t}^{1 / 2}$ will be linear and if it passes through the origin, then the determinant rate process is due only to intra-particle diffusion

It can be seen from Figure $9 \mathrm{c}$ that the experimental data is distributed along two straight lines. The first sharpened portion is attributed to the diffusion of the ad- sorbate by solution to the external surface of the sorbent (external diffusion), and the second portion describes the step of gradual adsorption, corresponding to the diffusion of adsorbate within the pores of the sorbent (intra-particle diffusion). It is also noted that $\mathrm{k}_{\mathrm{id} 1}>\mathrm{k}_{\mathrm{id} 2}$. Parameters obtained from the kinetic models are presented in Table 4.

From experimental data we can conclude that the adsorption of $\mathrm{Al}$ (III) ions follows the pseudo-second order kinetic model, which assumes that chemisorption can be the determining rate step.

In order to determine the effectiveness of the used sorbents, a comparison was made with the results from the literature when other sorbents were used, the results of the comparison being presented in Table 5 .

Comparing the experimental data obtained in this study with those obtained by other researchers, we can see that the sorbents used have a higher sorption capacity than some sorbents reported in the literature, which recommends them to use in the removal process of aluminium ions from the waste water.
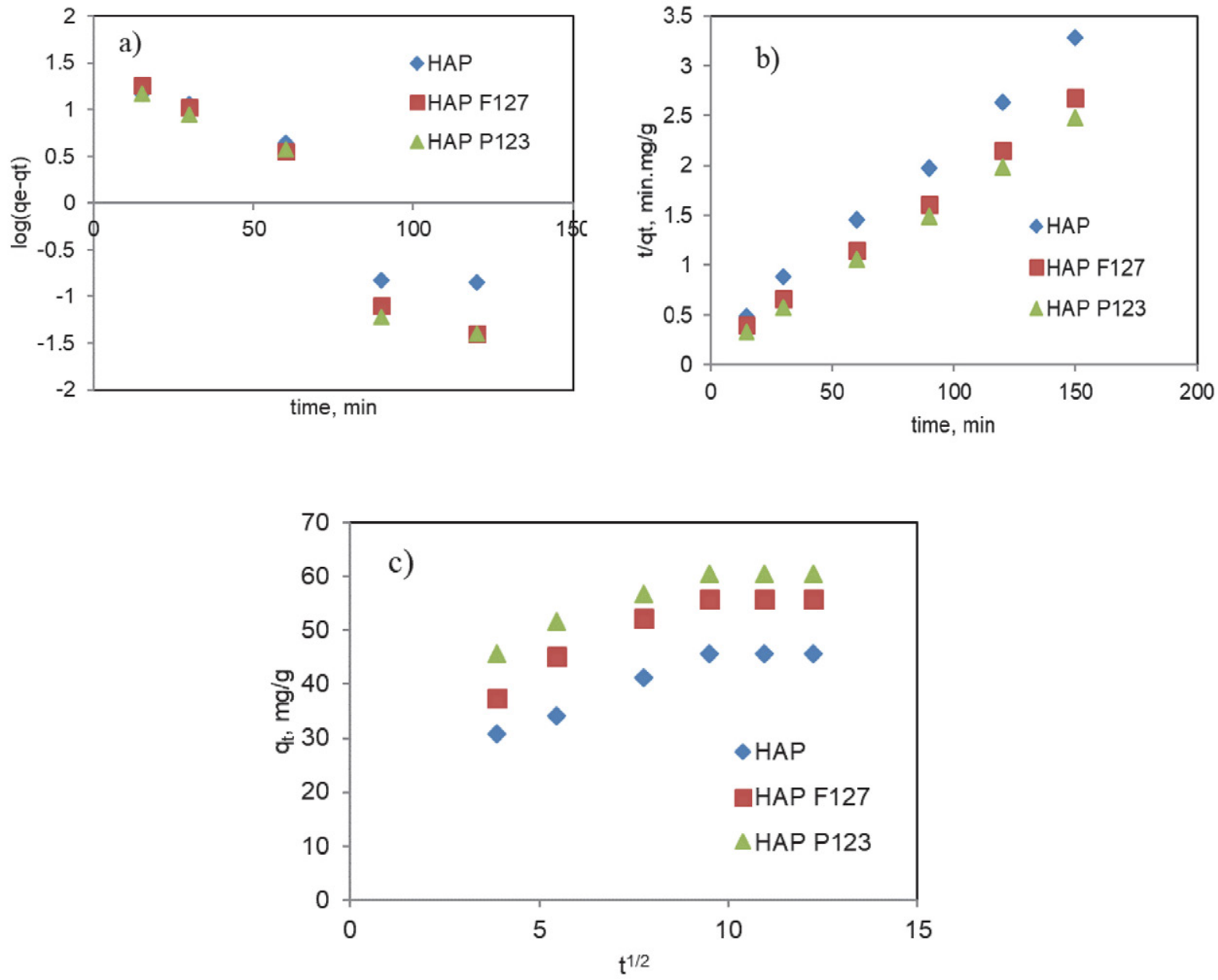

Figure 9. Pseudo-first order (a), pseudo-second order (b) and intraparticle diffusion kinetic model (c) for $\mathrm{Al}(\mathrm{III})$ adsorption onto investigated sorbents. 
Table 4. Kinetic parameters of the adsorption of $\mathrm{Al}(\mathrm{III})$ ions.

\begin{tabular}{|c|c|c|c|}
\hline $\begin{array}{l}\text { Kinetic model } \\
\text { Pseudo first order }\end{array}$ & HAP & $\begin{array}{l}\text { Sorbent } \\
\text { HAP F127 }\end{array}$ & HAP P123 \\
\hline $\begin{array}{l}\mathrm{q}_{\mathrm{e}, \exp }\left(\mathrm{mg} \mathrm{g}^{-1}\right) \\
\mathrm{q}_{\mathrm{e}, \text { calc }}\left(\mathrm{mg} \mathrm{g}^{-1}\right) \\
\mathrm{k}_{1}\left(\mathrm{~min}^{-1}\right) \\
\mathrm{R}^{2}\end{array}$ & $\begin{array}{l}45.67 \\
43.61 \\
0.051 \\
0.901\end{array}$ & $\begin{array}{l}55.9 \\
54.60 \\
0.064 \\
0.940\end{array}$ & $\begin{array}{l}60.54 \\
66.91 \\
0.063 \\
0.914\end{array}$ \\
\hline $\begin{array}{l}\text { Pseudo second orc } \\
\mathrm{q}_{\mathrm{e}, \exp }\left(\mathrm{mg} \mathrm{g}^{-1}\right) \\
\mathrm{q}_{\mathrm{e}, \text { calc }}\left(\mathrm{mg} \mathrm{g}^{-1}\right) \\
\mathrm{k}_{2}\left(\mathrm{~g} \mathrm{mg}^{-1} \mathrm{~min}^{-1}\right) \\
\mathrm{R}^{2}\end{array}$ & $\begin{array}{l}\text { der } \\
45.67 \\
49.62 \\
1.9110^{-3} \\
0.998\end{array}$ & $\begin{array}{l}55.9 \\
59.52 \\
1.9710^{-3} \\
0.999\end{array}$ & $\begin{array}{l}60.54 \\
63.29 \\
1.1610^{-3} \\
0.998\end{array}$ \\
\hline $\begin{array}{l}\text { Intraparticle difus } \\
\mathrm{k}_{\mathrm{id} 1}\left(\mathrm{mg} / \mathrm{g} \mathrm{min}^{1 / 2}\right) \\
\mathrm{k}_{\mathrm{id} 2}\left(\mathrm{mg} / \mathrm{g} \min ^{1 / 2}\right) \\
\mathrm{C}_{1} \\
\left(\mathrm{R}_{1}\right)^{2}\end{array}$ & $\begin{array}{l}\text { ssion } \\
2.703 \\
0.054 \\
20.024 \\
0.989\end{array}$ & $\begin{array}{l}3.781 \\
0.029 \\
23.476 \\
0.986\end{array}$ & $\begin{array}{l}2.814 \\
0.0216 \\
35.378 \\
0.979\end{array}$ \\
\hline
\end{tabular}

Table 5. Comparative result of adsorption efficiency of different type of sorbents towards $\mathrm{Al}(\mathrm{III})$

\begin{tabular}{lll}
\hline Sorbent & $\mathbf{q}_{\mathbf{e}}, \mathbf{m g} \mathbf{g}$ & Reference \\
\hline Beach cast seaweed & 22.49 & 5 \\
PAN beads & 0.245 & 18 \\
PAN beads thermally treated & 0.154 & 18 \\
Rice hull activated carbon & 34.48 & 1 \\
BDH activated carbon & 6.56 & 11 \\
Rhodococcus opacus & 41.58 & 50 \\
Granular activated carbon & 106.5 & 12 \\
Amberlite-IR-120H & 108.7 & 12 \\
Chitine & 18.28 & 51 \\
Chitosan & 23.57 & 51 \\
Hydroxyapatite & 104.17 & This study \\
Hydroxyapatite F127 & 109.89 & This study \\
Hydroxyapatite P123 & 117.65 & This study \\
\hline
\end{tabular}

\section{9. Regeneration and Reusability of Sorbents}

The applicability of potential sorbents depends on their regeneration under convenient conditions and the possibility of their re-use in successive sorption / desorption cycles. From practical reasons, an ideal sorbent must be reused in successive sorption/desorption cycles with as less as possible loss of the initial sorption capacity. Therefore, desorption of $\mathrm{Al}$ (III) ions was carried out with a 0.01 $\mathrm{M}$ solution of $\mathrm{HCl}$ obtained in five successive sorption/ desorption cycles as shown in Figure 10.

The results show that these sorbents could be successfully regenerated and repeatedly used in the adsorption studies of $\mathrm{Al}$ (III) ions without significant loss in their adsorption capacities.

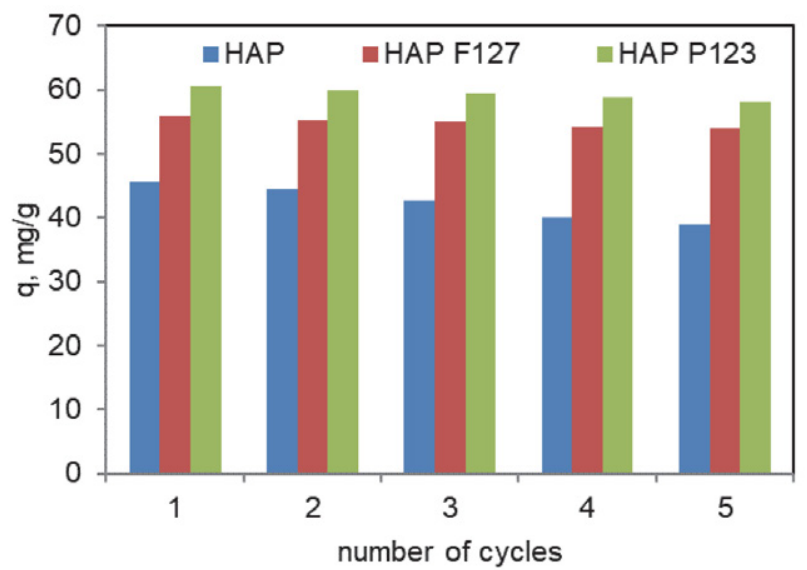

Figure 10. Cycles of desorption-adsorption for sorbents.

\section{Conclusions}

The sorption of aluminium (III) ions from synthetic wastewaters onto different type of hydroxyapatite has been studied as a function of contact time, the initial metal ion concentration, sorbent mass, $\mathrm{pH}$, sorbent dose and temperature. Equilibrium, kinetic and thermodynamic data were applied in order to evaluate the efficiency of the investigated sorbents for the removal of $\mathrm{Al}$ (III) ions from residual waters. The adsorption process of these ions on the three types of sorbents obeyed of the pseudo-second order kinetics, supporting that the chemisorption would be the rate-determining step. The equilibrium data obtained for the adsorption of aluminium ions onto investigated sorbents well fitted in the Langmuir model with a maximum theoretical adsorption capacity of $104.17 \mathrm{mg}$ $\mathrm{Al}(\mathrm{III}) / \mathrm{g}$ hydroxyapatite, and $109.84 \mathrm{mg} \mathrm{Al}(\mathrm{III}) / \mathrm{g}$ hydroxyapatite $\mathrm{F} 127$, and $117.65 \mathrm{mg} \mathrm{Al}(\mathrm{III}) / g$ hydroxyapatite F127, respectively. The sorption process is endothermic $\left(\Delta \mathrm{H}^{\circ}>20 \mathrm{~kJ} / \mathrm{mol}\right)$ and spontaneous (the increase of the negative values of $\Delta \mathrm{G}^{\circ}$ with the increase of temperature). The uptake of $\mathrm{Al}(\mathrm{III})$ by these sorbents is a reversible process and the sorbents can be used in five desorption/sorption cycles without significant loss in their adsorption capacities.

All these experimental results showed that hydroxyapatites are suitable adsorbent for removal of aluminium ions from residual waters.

\section{Acknowledgement}

This work was supported by IUCN-Dubna project, no. 03-4-1128-2017/2019, theme 100.

\section{References}

1. N. T. Abdel-Ghani, G. A. El-Chaghaby, E. M. Zahran, Am. J. Anal. Chem. 2015, 6, 71-83. DOI:10.4236/ajac.2015.61007 
2. N. T. Abdel-Ghani, A. K. Hegazy, G. A. El-Chaghaby, Int. J. Environ. Sci. Technol., 2009, 6, 243-248.

DOI:10.1007/BF03327628

3. P. T. Srinivasan, T. Viraraghavan, K. S. Subramanyam, Water $S A, 1999,25,47-55$.

4. M. E. Argun, Ş. Dursun, C. Özdemir, M. Karataş, J. Hazard. Mater. 2007, 141,77-85. DOI:10.1016/j.jhazmat.2006.06.095

5. P. Lodeiro, A. Gudina, L. Herrero, R. Herrero, M. E. Sastre de Vicente, J. Hazard. Mater. 2010, 178, 861-866.

DOI:10.1016/j.jhazmat.2010.02.017

6. S. Arendze, M. S. Sibiya, Water Sci. Tech. - Water Supply, 2017, 17, 733-744. DOI:10.2166/ws.2016.170

7. C. N. Martyn, C. Osmond, J. A. Edwardson, D. J. Barker, E. C. Harris, J. A. Edwardson, R. F. Lacey, The Lancet 1989, 333, 59-62. DOI:10.1016/S0140-6736(89)91425-6

8. M. V. Peto, Rejuv. Res. 2010, 13, 589-598. DOI:10.1089/rej.2009.0995

9. A. Tassist, H. Lounici, N. Abdi, N. Mameri, J. Hazard. Mater. 2010, 183, 35-43. DOI:10.1016/j.jhazmat.2010.06.078

10. P. G. Pour, M. A. Takassi, T. Hamoule, Orient.J. Chem. 2014, 30, 1365-1369. DOI:10.13005/ojc/300356

11. S. A. Al-Muhtaseb, M. H. El-Naas, S. Abdallah, J. Hazard. Mater. 2008, 158, 300-307. DOI:10.1016/j.jhazmat.2008.01.080

12. M. E. Goher, A. M. Hassan, I. A. Abdel-Moniem, A. H. Fahmy, M. H. Abdo, S. M. El-sayed, Egypt. J. Aquat. Res. 2015, 41, 155-164. DOI:10.1016/j.ejar.2015.04.002

13. A. M. Abdullah, J. Pollut. Eff. Cont. 2012, 2, 120-124. DOI: $10.4172 / 2375-4397.1000120$

14. F. Ji, C. Li, J. Xu, P. Liu, Coll. Surf. A Physicochem. Eng. Asp. 2013, 434, 88-94. DOI:10.1016/j.colsurfa.2013.05.045

15. D. Pitre, A. Boullemant, C. Fortin, Chem. Cent. J. 2014, 8, 8-15. doi: DOI:10.1186/1752-153X-8-8

16. A. Sari, M. Tuzen, J. Hazard. Mater. 2009, 171, 973-979. DOI:10.1016/j.jhazmat.2009.06.101

17. R. Asrarian, R. Jadidian, H. Parham, S. Haghtalab, Adv. Mater. Res. 2014, 829, 752-756.

DOI:10.4028/www.scientific.net/AMR.829.752

18. Z. Aly, A. Graulet, N. Scales, T. Hanley, Environ. Sci. Pollut. Res. 2014, 21, 3972-3986. DOI:10.1007/s11356-013-2305-6

19. F. An, B. Gao, X. Huang, Y. Zhang, Y. Li, Y. Xu, Z. Zhang, J. Gao, Z. Chen, React. Funct. Polym. 2013, 73, 60-65. DOI:10.1016/j.reactfunctpolym.2012.08.022

20. A. Islam, A. Hilal, N. Zaidi, S. Yadav, Ind. Eng. Chem. Res. 2013, 52, 5213-5220. DOI:10.1021/ie303300u

21. G. N. Kousalya, G. M. Rajiv, C. Sairam Sundaram, S. Meenakshi, Carbohydrate Polym. 2010, 82, 594-599.

DOI:10.1016/j.carbpol.2010.05.013

22. Duyen Thi Le, Thao Phuong Thi Le, Hai Thi Do, Hanh Thi Vo, Nam Thi Pham, Thom Thi Nguyen, Hong Thi Cao, Phuong Thu Nguyen, Thanh Mai Thi Dinh, Hai Viet Le, Dai Lam Tran, J. Chem., 2019, Article ID 8620181

DOI:10.1155/2019/8620181

23. W. Lemlikchi, P. Sharrock, M. O. Mecherri, M. Fiallo, Ange Nzihou, Waste and Biomass Valorization, Springer, 2012, 3 (1), 75-79. DOI:10.1007/s12649-011-9096-0

24. A. Paz, D. Guadarrama, M. López, J. E. González, N. Brizuela,
J. Aragón, Quim. Nova 2012, 35, 1724-1727. DOI:10.1590/S0100-40422012000900004

25. S. Park, A. Gomez-flores, Y. S. Chung, H. Kim, J. Chem. 2015, 396290. DOI: $10.1155 / 2015 / 396290$

26. G. Ciobanu, M. Harja, L. Rusu, A. M. Mocanu, C. Luca, Korean J. Chem. Eng. 2014, 31, 1021-1027.

DOI:10.1007/s11814-014-0040-4

27. T. A. Salah, A. M. Mohammad, M. A. Hassan, B. E. El-Anadouli, J. Taiwan Inst. Chem. Eng. 2014, 45, 1571-1577.

DOI:10.1016/j.jtice.2013.10.008

28. P. Wang, C. Li, H. Gong, X. Jiang, H. Wang, K. Li, Powder Technol. 2010, 203, 315-321. DOI:10.1016/j.powtec.2010.05.023

29. A. I. Adeogun, R. B. Babu, Appl. Nanosci. 2015, 5, 1-13. DOI:10.1007/s13204-015-0484-9

30. M. S. M. Arsad, P. M. Lee, L. K. Hung, 2nd International Conference on Biotechnology and Food Science IPCBEE 7, 2011 , 184-188.

31. N. Barka, S. Qourzal, A. Assabbane, A. Nounah, Y. Ait-Ichou, J. Saudi Chem. Soc. 2011, 15, 263-267.

DOI:10.1016/j.jscs.2010.10.002

32. D. C. Manatunga, R. M. de Silva, K. M. Nalin de Silva, N. de Silva, E. V. A. Premalal, R. Soc. Open Sci. 2018, 5, 171557171571. DOI:10.1098/rsos.171557

33. S. Wongsakulphasatch, Eng. J. 2010, 17, 30-37. DOI:10.4186/ej.2013.17.2.29

34. W. Aili, L. Dong, Y. Hengbo, W. Huixiong, W. Yuji, R. Min, J. Tingshun, C. Xiaonong, X. Yiqing, J. Mat. Sc. Eng. 2007, C27, 865-869. DOI:10.1016/j.msec.2006.10.001

35. G. M. El Shafei, C. A. Philip, N. A. Moussa, J. Coll. Interf. Sci. 2004, 277, 410-416. DOI:10.1016/j.jcis.2004.05.002

36. K. S. W. Sing, D. H. Everett, R. A. W. Haul, L. Moscou, R. A. Pierotti, J. Rouquérol, T. Siemieniewska, Pure Appl. Chem. 1985, 57, 603-619. DOI: $10.1351 / \mathrm{pac} 198557040603$

37. J. R. Nimmo, Soil Sci. Soc. Am. J. 1992, 56, 1723-1730. DOI:10.2136/sssaj1992.03615995005600060011x

38. R. Garcidueñas Piña, C. Cervantes, Biol. Met. 1996, 9, 311316. DOI:10.1007/BF00817932

39. Z. Aly, A. Graulet, N. Scales, T. Hanley, Environ. Sci. Pollut. Res. 2014, 21, 3972-3986. DOI:10.1007/s11356-013-2305-6

40. S. A. Al-Muhtaseb, M. H. El-Naas, S. Abdallah, J. Hazard. Mater., 2008, 158, 300-307. DOI:10.1016/j.jhazmat.2008.01.080

41. A. Ramdani, Z. Taleb, A. Guendouzi, A. Kadeche, H. Herbache, A. Mostefai, S. Taleb, A. Deratani, Can. J. Chem., 2020, 98, 79-89. DOI:10.1139/cjc-2019-0315

42. I. Langmuir, J. Am. Chem. Soc. 1916, 38, 2221-2295. DOI:10.1021/ja02268a002

43. H. Freundlich, Zeitschrift für Physikalische Chemie 1906, 57, 385-470. DOI:10.1515/zpch-1907-5723

44. C. H. Giles, D. Smith, A. Huitson, J. Coll. Interf. Sci. 1974, 47, 755-765. DOI:10.1016/0021-9797(74)90252-5

45. M. M. Dubinin, L. V. Radushkevich, Physical Chemistry Section USSR, 1947, 55, 331-333.

46. M. Temkin, Zhurnal Fizicheskoi Khimii 1941, 15, 296-332.

47. S. Lagergren, B. K. Svenska, R. Swed. Acad. Sci. Doc. Band. 1898, 24, 1-13. 
48. G. McKay, Y. S. Ho, Proc. Biochem. 1999, 34, 451-465.

DOI:10.1016/S0032-9592(98)00112-5

49. W. J. Jr. Weber, J. C. Morris, J. Sanit. Eng. Div. Am. Soc. Civ. Eng. 1963, 89, 31-59. DOI:10.1061/JSEDAI.0000430
50. J. E. B. Cayllahua, M. L. Torem, (2010) Chem. Eng. J. 2010, 161, 1-8. DOI:10.1016/j.cej.2010.03.025

51. M. Á. Lobo-Recio, F. R. Lapolli, T. J. Belli, C. T. Folzke, R. R. Zepon Tarpani, Des. Water Treat. 2013, 51, 1735-1743.

DOI:10.1080/19443994.2012.715133

\section{Povzetek}

V tem delu predstavljamo rezultate sposobnosti adsorpcije aluminija iz onesnažene vode s hidroksiapatitom pripravljenim na različne načine. Eksperimenti so bili izvedeni v šaržnem načinu pri različnih pH vrednostih, temperaturi, količini adsorbenta, kontaktnem času in začetni koncentraciji aluminija. Termodinamska analiza je pokazala, da je proces adsorpcije aluminija na hidroksiapatit spontan in endotermen. Eksperimentalnim podatkom smo prilagajali Langmuirjev, Freundlichov, Flory-Hugginsov, Dubinin-Radushkevichov in Temkinov ravnotežni model, pri čemer smo najboljše ujemanje dosegli z Langmuirjevim modelom. Kinetične podatke smo ovrednotili s kinetičnim modelom psevdo-prvega in psevdo-drugega reda ter modelom znotrajdelčne difuzije. Hitrost adsorpcije aluminija lahko najbolje opišemo s psevdo-drugim redom. Rezultati so pokazali, da ima najvišjo adsorpcijsko kapaciteto aluminija hidroksiapatit pri katerem smo uporabili surfaktant Pluronic P123 (117.65 $\mathrm{mg} \mathrm{g}^{-1}$ ), sledi mu hidroksiapatit s surfaktantom Pluronic F127, najnižjo pa hidroksiapatit pripravljen brez uporabe surfaktanta $\left(104.17 \mathrm{mg} \mathrm{g}^{-1}\right)$.

Except when otherwise noted, articles in this journal are published under the terms and conditions of the Creative Commons Attribution 4.0 International License 